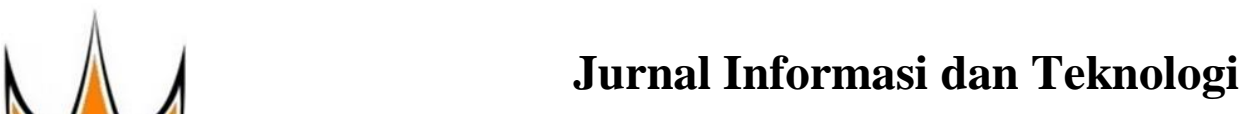

http://www.jidt.org

2022 Vol. 4 No. $1 \quad$ Hal: $1-8$

e-ISSN: 2714-9730

\title{
Kebijakan Pembatasan Sosial Berkala: Prediksi Sikap Masyarakat Terhadap Telemedis Selama Pandemi COVID-19
}

\author{
Tiar Anindya Putri ${ }^{1 凶}$ \\ ${ }^{1}$ Institut Teknologi Telkom Surabaya \\ tiar.ap@itte1kom-sby.ac.id
}

\begin{abstract}
Telemedicine can provide routine care services without the risk of contracting Covid-19 in online way in the government's policy for social restrictions and adaptation of new habits stages. This study was intended to assess attitudes in the direction of telemedicine at some stage in periodical social restrictions in Indonesia, then examine the general public's willingness to use the service within the future, and also examine the extent to which respondent have changed their minds about the service. This study uses two statistical analysis approaches. The first approach was a cross-sectional, descriptive, and correlational study conducted among adults aged over 19 years using social media networks. Then the second approach is Ordered Logistic Regression models on two questionnaire items for the dependent variable, specifically predicting willingness to apply telemedicine within the future and predicting changes in thoughts about telemedicine. Sixty-four percent of respondents agree and strongly agree that they need to use telemedicine during the periodical social restriction period of the COVID-19 pandemic. However, despite the availability of telemedicine during the COVID-19 pandemic, $46.92 \%$ of respondents tend to still like to go to clinics or hospitals. A total of $24.64 \%$ of respondents were hesitant to go to a clinic or hospital, and $28.44 \%$ of respondents were hesitant to go to a clinic or hospital. This makes telemedicine in Indonesia not yet considered a necessity, but is still considered the first solution that can be done on a periodic basis.
\end{abstract}

Keywords: telemedicine, cross-sectional study, ordered logistic regression, periodical social restriction, adaptation of new habits.

\begin{abstract}
Abstrak
Kebijakan pemerintah untuk pembatasan sosial berkala dan Adaptasi Kebiasaan Baru (AKB), mendorong masyarakat untuk menyesuaikan perilaku dengan menyesuaikan diri mematuhi protokol kesehatan yang ditetapkan sejak hadirnya pandemi COVID-19 di Indonesia. Pada sektor kesehatan, penyesuaian dilakukan dengan gencarnya pelayanan kesehatan masyarakat secara daring berupa layanan telemedis secara daring. Meskipun Telemedis menawarkan banyak manfaat potensial, namun penggunaannya masih menjadi tantangan di masyarakat. Tujuan dari penelitian ini adalah untuk mengevaluasi sikap terhadap Telemedis selama masa pembatasan sosial dan AKB pandemi COVID-19 di Indonesia, kemudian menilai kesediaan masyarakat untuk menggunakan layanan tersebut di masa depan, dan mengevaluasi sejauh mana responden telah berubah pikiran tentang layanan ini. Penelitian ini menggunakan dua pendekatan analisis statistik. Pendekatan pertama adalah studi cross-sectional, deskriptif, dan korelasional yang dilakukan di antara orang dewasa berusia diatas 19 tahun (> 20 tahun) menggunakan jaringan media sosial $(\mathrm{N}=203)$. Kemudian pendekatan kedua adalah Ordered Logistic Regression Models pada dua butir kuesioner untuk variabel dependen, yaitu memprediksi kesediaan menggunakan telemedis di masa depan dan memprediksi perubahan pikiran tentang telemedis. Data dikumpulkan menggunakan kuesioner online. Enam puluh empat persen responden setuju dan sangat setuju bahwa mereka perlu menggunakan telemedis selama masa kebijakan pembatasan sosial dan AKB pendemi COVID-19. Namun, 46,92\% responden cenderung tetap lebih suka pergi ke klinik atau rumah sakit. Sebanyak $24,64 \%$ responden ragu untuk pergi ke klinik atau rumah sakit, dan 28,44\% responden enggan untuk pergi ke klinik atau rumah sakit. Hal ini menjadikan telemedis di Indonesia belum dianggap kebutuhan, namun masih dianggap jalan keluar pertama pada saat pembatasan sosial berkala.
\end{abstract}

Kata kunci: Telemedis, Studi Cross-Sectional, Ordered Logistic Regression, Korelasional, Pembatasan Social Berkala, Adaptasi Kebiasaan Baru (AKB).

\section{Pendahuluan}

Pemerintah Indonesia sudah melakukan berbagai cara dalam menanggulangi dan mencegah penyebaran virus COVID-19. Pandemi ini telah berlangsung sejak awal tahun 2020 di Indonesia. Beragam kebijakan telah dilakukan, salah satunya adalah pembatasan sosial berkala. Kebijakan ini dilakukan dalam rangka membatasi pergerakan masyarakat tanpa harus menutup total (lockdown). Kebijakan ini mendorong masyarakat untuk beradaptasi pada kebiasaan baru.
Suatu survey yang dilakukan oleh Badan Pusat Statistik (BPS), memberikan hasil perihal penanganan pandemi. Survei sikap masyarakat selama masa pandemi COVID-19 ini dilakukan secara daring. Survei ini memberikan informasi perihal persepsi kepatuhan, efektivitas pelaksanaan protokol kesehatan, dan penilaian terhadap pandemi COVID-19. kiprah media pada penyampaian berita COVID-19, dan aspek lain wacana tatanan kehidupan masyarakat di masa pandemic juga termasuk pada informasi lapangan tersebut. dua topik yang menarik perhatian peneliti di 
survey tersebut merupakan perbandingan frekuensi tidak hanya mengubah sistem pemberian kesehatan keluar tempat tinggal saat ini menggunakan sebelum tetapi juga meningkatkan efektivitas layanan perawatan adaptasi kebiasaan baru (AKB) lalu persepsi responden kesehatan [7]. Telemedis atau telehealth telah ada menggunakan kemungkinan terinfeksi atau tertular selama beberapa dekade; namun, penggunaan layanan COVID-19. Dibandingkan sebelum AKB, 38,75\% ini tetap rendah, meskipun ada banyak sekali manfaat responden lebih jarang keluar rumah dan 20,08\% yang diberikan. Dalam beberapa tahun terakhir, responden yang menyatakan lebih sering keluar rumah telemedis telah mendapatkan popularitas lebih di diketahui bahwa untuk kepentingan pekerjaan. negara-negara berkembang di mana banyak pemerintah Kemudian, $19,3 \%$ responden meyakini bahwa sangat mengakui kemungkinan manfaat telemedis dan telah mungkin terinfeksi atau tertular COVID-19, 29,4\% mengintegrasikannya ke dalam rencana mereka untuk meyakini bahwa mungkin terinfeksi atau tertular, dan memenuhi target sistem kesehatan mereka, seperti 34,3\% meyakini bahwa cukup mungkin terinfeksi atau tujuan pembangunan berkelanjutan [8], [9]. Seiring tertular [1]. Hasil dari survey ini dipergunakan oleh dengan adanya pandemi virus Covid-19 saat ini pemangku kepentingan buat menyusun perancanaan menempatkan telemedis menjadi sorotan, terutama di strategis pada penanganan pandemi COVID-19.

Masyarakat yg membutuhkan pelayanan kesehatan Indonesia dengan jumlah penduduk yang padat dan semakin ragu untuk datang langsung ke rumah sakit Platform telemedis dan perangkat lunak virtual adalah semenjak adanya pandemi COVID-19. Hal ini salah satu metode untuk mengelola pandemi COVIDdinyatakan oleh MarkPlus Inc. pada edisi ke-20 19 [10], [11]. Sesuai dengan Permenkes Nomor 20 MarkPlus Industri Roundtable tentang institusi Tahun 2019 tentang penyelenggaraan pelayanan Kesehatan yang menyatakan bahwa $72 \%$ responden telemedis antar fasilitas pelayanan kesehatan, hadirnya menyatakan bahwa mereka tidak pernah mengunjungi platform telemedis diharapkan menjadi pelayanan rumah sakits ataupun klinik sekalipun semenjak adanya Kesehatan jarak jauh menggunakan teknologi yang pandemic COVID-19 [2]. Sehingga, Untuk berisikan tentang komunikasi, pertukaran info mengakomodir pelayanan kesehatan masyarakat diagnosis, pengobatan, pencegahan penyakit. Platform dengan adanya kekhawatiran masyarakat Indonesia ini dapat digunakan sebagai penelitian serta penilaian untuk keluar rumah dan mencegah tertular COVID-19, untuk pendidikan berkelanjutan, juga diharapkan dapat masyarakat dapat memanfaatkan platform telemedis meningkatkan ketersediaan layanan dan peningkatan untuk diagnosis dini terhadap suatu penyakit yang kesehatan masyarakat.

diberikan secara virtual. Digitalisasi layanan kesehatan dapat meningkatkan efisiensi dan memungkinkan penyediaan layanan kesehatan berkualitas lebih baik, menawarkan banyak manfaat bagi pemangku kepentingan [3]. Banyak solusi teknologi inovatif telah muncul belakangan ini untuk memenuhi kebutuhan masyarakat terkait kesehatan [4]. Sebagai bidang yang baru muncul di industri perawatan kesehatan, layanan kesehatan seluler semakin mendapat perhatian dalam beberapa tahun terakhir [5].

Kementerian Kesehatan mengeluarkan Peraturan pada Pasal 1 angka 1 Peraturan Menteri Kesehatan Nomor 20 Tahun 2019 mengenai penyelenggaraan pelayanan telemedis antar fasilitas pelayanan kesehatan ("Permenkes 20/2019"). Peraturan ini menjelaskan tentang telemedis, yaitu berupa pemberian pelayanan kesehatan jarak jauh oleh profesional kesehatan dengan menggunakan teknologi informasi dan komunikasi, hal ini dilakukan meliputi pertukaran informasi diagnosis, pengobatan, pencegahan penyakit dan cedera, Alat Kesehatan seluler, yang dikenal sebagai telemedis, penelitian dan evaluasi, serta pendidikan berkelanjutan muncul karena peningkatan penggunaan teknologi mengenai penyedia layanan kesehatan untuk seluler dan konektivitasnya untuk mengakses informasi kepentingan peningkatan kesehatan individu dan juga terkait Kesehatan. Hal ini didukung oleh pernyataan masyarakat [12]. Peraturan ini memungkinkan Direktur Jendral Penyelenggaraan Pos dan Informatika penyedia yang memenuhi syarat untuk menagih Kementerian Komunikasi dan Informatika, Ahmad M Medicare untuk perawatan yang diberikan melalui Ramli, pada diskusi berjudul Satu Jam Berbincang Ilmu telemedis.

tentang Polemik UU ITE bahwa pengguna internet pada awal tahun 2021 ini mencapai 202,6 juta jiwa di Indonesia. Jaffe dkk. [6] mencatat bahwa akses serta penggunaan teknologi digital sudah meningkat secara dramatis dalam dasa warsa terakhir pada antara orang dewasa. Terlepas dari perbedaan rentang usia, digitalisasi sudah menjadi bagian dari kehidupan sehari-hari dan adanya telemedis diharapkan dapat digunakan secara optimal untuk membantu dalam keadaan keterbatasan.

Selanjutnya, dalam upaya untuk mengurangi risiko penularan virus, penyedia layanan kesehatan semakin gencar menjadwalkan dan menemui pasien melalui telemedis. Pasien dan praktisi medis di seluruh dunia sudah mengadopsi telemedis dan platform perangkat lunak virtual, mengalami potensi mereka, dan menetapkan harapan dan kenyamanan perangkat lunak ini untuk diagnosis dini dan tindak lanjut [13]. Dengan demikian, telemedis dan platform perangkat lunak virtual terkait dapat membantu mengurangi penyebaran Aplikasi telemedis telah digunakan secara luas, dan COVID-19 selama karantina dan jarak sosial. Mungkin, telah terjadi banyak perkembangan layanan baru yang telemedis harus diadopsi sebagai tindakan proaktif

Jurnal Informasi dan Teknologi Vol. 4 No. 1 (2022) 1-8 
untuk meningkatkan perawatan medis dan tidak hanya juli 2021. Survey dilakukan pada bulan Juli hingga dilihat sebagai perbaikan sementara pada saat darurat; Agustus 2021.

melainkan, ini adalah metode yang nyaman, aman,

terukur, efektif, dan ramah lingkungan dalam 2.1. Pengumpulan Data dan Desain Sampel memberikan perawatan medis [14]. Meskipun, adopsi telemedis tidak dapat sepenuhnya menyelesaikan semua masalah yang disebabkan oleh COVID-19, itu dapat membantu meratakan kurva infeksi COVID-19.

Data dikumpulkan menggunakan kuesioner online yang secara eksplisit dirancang untuk mengukur sikap terhadap telemedis. Pertama, peneliti melakukan studi percontohan dilakukan untuk mengevaluasi reliabilitas Penelitian sebelumnya [15] telah dilakukan dengan dan validitas kuesioner. Kemudian penyebaran metode yang sama pada negara Israel. Namun, pada kuisioner yang sudah siap dilakukan melalui media penelitian ini, fokus penelitian dilakukan pada daerah sosial. Peneliti juga menggunakan sampel rujukan dengan Kebjakan Pembatasan Sosial di Indonesia. berantai melalui jejaring sosial seperti Facebook, Kebijakan ini berbeda dengan penelitian sebelumnya Telegram, Instagram, dan WhatsApp. yang terjadi pada keadaan penutupan keseluruhan (lockdown). Di Indonesia, penutupan dilakukan hanya 2.2. Pengukuran Instrumen

Sebagian, pergerakan masyarakat masih terjadi walaupun tidak pada keseluruhan sektor. Sehingga, tujuan dari penelitian ini adalah untuk mengevaluasi sikap terhadap telemedis selama pembatasan berkala COVID-19 di Indonesia, menilai kesediaan untuk menggunakan layanan tersebut di masa depan, dan mengevaluasi sejauh mana konsumen telah berubah pikiran mengenai layanan ini. Hal ini dilakukan untuk mengevaluasi sikap konsumen terhadap perawatan kesehatan mengenai telemedis selama masa pembatasan sosial dan Adaptasi kebiasaan Baru (AKB) akibat COVID-19 di Indonesia.

Peneliti tertarik untuk meneliti penyebab dari penggunaan telemedis elama wabah ini dan untuk memprediksi sikap konsumen terhadap penggunaan telemedis selama perubahan ekonomi yang tidak dapat diprediksi. Fokus lain yang dilakukan pada penelitian ini adalah masyarakat umum usia produktif. Hal ini dilakukan sesuai literatur yang menyatakan bahwa dengan potensi pembaur, individu yang lebih muda lebih cenderung menggunakan telemedis daripada individu dewasa [16]. Kemudian, hasil bermanfaat lain yang diharapkan dari penelitian ini adalah dapat mengevaluasi pangsa pasar telemedis dari populasi adalah bahwa hal itu akan memungkinkan pemerintah untuk mengidentifikasi berbagai tingkat literasi di antara masyarakat dengan berbagai latar belakang sosiodemografi dan menghasilkan respons yang sesuai.

\section{Metodologi Penelitian}

Sebuah studi cross-sectional, deskriptif, korelasional dilakukan di antara orang dewasa (usia 20-90) menggunakan jaringan media sosial yang dilakukan sebagai bagian dari studi yang lebih luas untuk mengukur sikap terhadap telemedis dan memetakan kemungkinan hambatan yang mungkin dialami pasien dalam menggunakan layanan tersebut. Dikarenakan pandemi COVID-19, pendataan dilakukan melalui survei online yang tersebar di antara calon peserta yang berdomisili di Pulau Jawa dan Bali. Domisisli ini dijadikan acuan penelitian karena pembatasan berkala yang dilaksanakan sebagai aspek penelitian dilakukan secara serentak berfokus di Pulau Jawa dan Bali sejak 3

Kuesioner dirancang untuk menilai sikap responden terhadap layanan telemedis selama Kebijakan Pembatasan Sosial dan Adaptasi kebiasaan Baru (AKB) pada masa pandemi COVID-19 sesuai dengan studi kasus sebelumnya yang telah dilakukan di negara lain [15]. Kuesioner mencakup lima pernyataan pada skala Likert lima poin (1 "Sangat tidak setuju" hingga 5 "Sangat setuju"). Partisipan diminta untuk mengungkapkan sejauh mana ketidaksetujuan mereka terhadap setiap pernyataan berikut:

a. Butir 1, Perlunya menggunakan telemedis: "Terisolasi selama krisis COVID-19 mengharuskan saya menggunakan telemedis untuk menerima perawatan atau konseling kesehatan."

b. Butir 2, Preferensi untuk pergi ke klinik: "Meskipun ketersediaan telemedis selama penguncian COVID-19, saya lebih suka pergi ke klinik."

c. Butir 3, Kepuasan terhadap layanan telemedis: "Secara umum, selama periode COVID-19, saya puas dengan layanan medis yang diberikan melalui teknologi digital."

d. Butir 4, Kesediaan untuk menggunakan telemedis di masa depan: "Saya akan terus menggunakan telemedis bahkan setelah pandemi COVID-19 berakhir."

e. Butir 5, Perubahan pikiran tentang telemedis: "Terisolasi selama krisis COVID-19 telah mengubah pikiran saya tentang penggunaan telemedis untuk kebutuhan kesehatan saya."

Selain itu, bagian sosio-demografis dimasukkan, mengumpulkan usia, jenis kelamin, status sosial ekonomi, pendidikan, dan adanya kondisi kronis.

\subsection{Metode Analisis Data}

Penelitian ini menggunakan dua pendekatan analisis statistik. Pertama, peneliti menggunakan analisis deskriptif pada sampel $(\mathrm{N}=211)$, kemudian peneliti fokus menganalisis populasi dewasa berusia diatas 20 tahun dan $(\mathrm{N}=203)$. Hal ini dilakukan karena kebutuhan 
responden untuk fokus penelitian adalah penelitian penyakit kronis, 5,21\% terdiagnosa 1 atau 2 penyakit pada manusia dewasa.

kronis, dan $1,9 \%$ terdiagnosa lebih dari 2 penyakit kronis. Oleh karena itu, penelitian ini akan Metode kedua yang dilakukan peneliti adalah Ordered melampirkan hasil dari dua kategori yaitu keseluruhan Logistic Regression Models [17] pada dua butir sampel yang didapat dan responden dewasa. Hal ini kuesioner untuk variabel dependen, yaitu Memprediksi dilakukan karena tingkat rawat inap tertinggi di antara Kesediaan Menggunakan Telemedis di Masa Depan orang dewasa berusia 65 tahun atau lebih, orang dengan (Butir 4) dan Memprediksi Perubahan Pikiran Tentang beberapa kondisi kronis, dan laki-laki, dimana di antara Telemedis (Butir 5). Untuk setiap variabel dependen, pasien yang lebih muda (18-49 tahun), obesitas, dilakukan beberapa proses yaitu implementasi beberapa penyakit paru kronis yang mendasari (terutama asma), model, memeriksa hubungan antara variabel bebas dan dan diabetes adalah gangguan kronis yang paling variabel dependen, menambahkan item telemedis, dan umum, dan virus COVID-19 diperkirakan akan menggunakan metode langkah maju (forward stepwise) menyerang lebih berbahaya pada manusia dengan sebagai metode pemilihan variable. Matriks evaluasi penyakit bawaan [19], [20]. Sehingga, seseorang digunakan untuk menguji kecocokan model (misalnya, dengan penyakit kronis lebih cenderung datang Bayesian Information Criterion-BIC; McFadden langsung ke rumah sakit karena tingkat kebutuhan akan Pseudo R2) [18]. Uji Likelihood-Ratio (LR test) kegawatan penyakitnya, dibandingkan dengan digunakan untuk menguji model bersarang (nested seseorang tanpa penyakit kronis yang lebih memilih models). Uji Brant dan diagnostik regresi lainnya telemedis sebagai solusi awal dalam mendeteksi serta digunakan untuk mengevaluasi asumsi model. Peneliti berkonsultasi terhadap hadirnya gejala penyakit.

menyajikan Average Adjusted Predictions (AAPs) dan Adjusted Predictions pada nilai Representatif (APRs) untuk kedua variabel dependen untuk kemudahan Enam puluh empat persen responden setuju dan sangat interpretasi. keseluruhan analisis regresi menggunakan setuju bahwa mereka perlu menggunakan telemedis kesalahan cluster yang kuat. Signifikansi statistik selama masa kebijakan pembatasan sosial dan Adaptasi ditetapkan pada nilai $\mathrm{p}$ adalah 0,05 .

\section{Hasil dan Pembahasan}

Di Indonesia, seperti di negara maju lainnya, pandemi COVID-19 telah mempercepat penggunaan telemedis. Studi saat ini meneliti sikap orang dewasa terhadap penggunaan telemedis selama penguncian parsial COVID-19. Hasil penelitian menunjukkan bahwa sebagian besar peserta lebih suka menggunakan telemedis dan puas dengan penggunaannya selama periode ini.

\subsection{Analisis Deskriptif}

Kebiasaan Baru (AKB) pendemi COVID-19 seperti yang disajikan pada Tabel 1. Namun, meskipun terdapat ketersediaan telemedis selama pembatasan pada masa pandemi COVID-19, tetapi 46,92\% responden cenderung tetap lebih suka pergi ke klinik atau rumah sakit. Sebanyak 24,64\% responden ragu untuk pergi ke klinik atau rumah sakit, dan $28,44 \%$ responden enggan untuk pergi ke klinik atau rumah sakit. Hal ini menjadikan telemedis di Indonesia belum dianggap kebutuhan, namun masih dianggap jalan keluar pertama yang bisa dilakukan di masa pembatasan berkala.

Tabel 1. Respon peserta (\%) pada lima butir kuesioner ( $\mathrm{n}=211)$.

Penelitian ini menggunakan sampel rujukan berantai melalui jejaring sosial seperti Instagram, Facebook, Telegram, dan WhatsApp. Hasilnya, sejumlah 211 responden dilibatkan, terdiri dari 110 perempuan $(52,13 \%)$ dan 101 laki-laki (47,87\%); rentang usia penelitian (seluruh sampel penelitian) adalah 18 tahun hingga 80 tahun dengan rincian delapan responden berusia <20 tahun dan >60 tahun, 179 responden berusia diantara 20 hingga 39 tahun, dan 16 responden berusia 40 hingga 59 tahun; pedidikan terakhir responden terdiri dari $18,96 \%$ lulusan SMA/SMK sederajat, 9,95\% lulusan diploma, 58,29\% lulusan sarjana, serta 12,80\% lulusan Magister atau diatasnya.

Rata-rata pendapatan responden setiap bulan dalam penelitian ini dikategorikan pada 3 kategori yaitu, $18,48 \%$ berpenghasilan di bawah UMR, 34,12\% berpenghasilan setara UMR, dan ada 47,39\% responden berpenghasilan diatas UMR. Kemudian peneliti juga mengamati yingkat Kesehatan responden. Hasilnya adalah 92,89\% responden tidak memiliki

\begin{tabular}{|lccccc|}
\hline & \multicolumn{1}{c}{$(\mathbf{1})$} & $\mathbf{( 2 )}$ & $\mathbf{( 3 )}$ & $\mathbf{( 4 )}$ & $\mathbf{( 5 )}$ \\
\cline { 2 - 6 } Butir & $\begin{array}{c}\text { Sangat } \\
\text { Tidak } \\
\text { Setuju }\end{array}$ & $\begin{array}{c}\text { Tidak } \\
\text { Setuju }\end{array}$ & Netral & Setuju & $\begin{array}{c}\text { Sangat } \\
\text { Setuju }\end{array}$ \\
\hline $\begin{array}{l}\text { (1) Butir 1, Perlunya } \\
\text { menggunakan } \\
\text { telemedis }\end{array}$ & 8,53 & 12,80 & 15,17 & 34,60 & 28,91 \\
$\begin{array}{l}\text { (2) Butir 2, Preferensi } \\
\text { untuk pergi ke klinik } \\
\text { (3) Butir 3, Kepuasan }\end{array}$ & 8,53 & 19,91 & 24,64 & 28,44 & 18,48 \\
$\begin{array}{l}\text { terhadap layanan } \\
\text { telemedis } \\
\text { (4) Butir 4, Kesediaan } \\
\text { untuk menggunakan }\end{array}$ & 5,69 & 18,48 & 27,01 & 28,44 & 20,38 \\
$\begin{array}{l}\text { telemedis di masa } \\
\text { depan }\end{array}$ & 7,58 & 25,12 & 28,44 & 23,22 & 15,64 \\
$\begin{array}{l}\text { (5) Butir 5, Perubahan } \\
\text { pikiran tentang }\end{array}$ & 7,11 & 16,11 & 24,17 & 32,23 & 20,38 \\
telemedis & & & & & \\
\hline
\end{tabular}

Sebesar $48,82 \%$ responden setuju dan sangat setuju bahwa pelayanan yang diberikan oleh aplikasi telemedis sudah memuaskan. Kemudian kesediaan responden untuk tetap menggunakan telemedis di masa 
depan cenderung netral karena hasil responden yang 3.3.2.Sampel spesifik populasi berusia 20 tahun keatas setuju dan sangat tidak setuju $(38,86 \%)$ hanya berselisih $6 \%$ lebih tinggi dibandingkan dengan responden yang memilih tidak setuju dan sangat tidak setuju.

$(\mathrm{N}=203)$ :

Peneliti menemukan bahwa perlunya menggunakan telemedis selama pembatasan sosial berkala COVID-19 pada sampel manusia dewasa, berkorelasi positif Meskipun demikian, masa masa kebijakan pembatasan dengan kepuasan terhadap layanan telemedis, sosial dan Adaptasi Kebiasaan Baru (AKB) ini telah kesediaan untuk menggunakan telemedis di masa mengubah pandangan responden tentang keberfungsian depan, dan dengan perubahan pikiran tentang telemedis. Sebanyak 52,61\% responden mengaku telemedis. Artinya, responden yang lebih setuju bahwa bahwa selama masa ini, telemedis menjadi salah satu mereka harus menggunakan atau menerima layanan yang sangat membantu.

\subsection{Korelasi Spearman's rank.} telemedis selama pembatasan sosial berkala COVID-19 adalah mereka yang puas terhadap layanan telemedis, lebih cenderung untuk terus menggunakan jenis Tabel Spearman dibangun dengan mempertimbangkan layanan ini di masa depan, serta kemungkinan besar semua kemungkinan kasus. Sehingga pada penelitian akan berubah pikiran mengenai kebermanfaatan jenis ini, perhitungan dilakukan dengan sampel berukuran layanan ini. Hasil sampel khusus ini berpola seupa 211 dan 203, dan peringkat butir data dengan dengan sampel keseluruhan, maka korelasi antara menggunakan skala likert yaitu dari 1 hingga 5 sesuai berbagai item adalah stabil.

dengan nilai variabel $\mathrm{X}$, maka peringkat yang sesuai untuk variabel $\mathrm{Y}$ akan menjadi angka 1 sampai 5 dalam beberapa urutan.

\subsubsection{Seluruh Sampel $(\mathrm{N}=211)$}

Peneliti menemukan bahwa perlunya menggunakan telemedis selama pembatasan sosial berkala COVID-19 berkorelasi positif dengan kepuasan terhadap layanan telemedis, kesediaan untuk menggunakan telemedis di masa depan, dan dengan perubahan pikiran tentang telemedis. Artinya, responden yang lebih setuju bahwa mereka harus menggunakan atau menerima layanan telemedis selama pembatasan sosial berkala COVID-19 adalah mereka yang puas terhadap layanan telemedis, lebih cenderung untuk terus menggunakan jenis layanan ini di masa depan, serta kemungkinan besar akan berubah pikiran mengenai kebermanfaatan jenis layanan ini.

Tabel 2. Korelasi spearman's rank pada lima butir kuesioner $(\mathrm{n}=211)$

\begin{tabular}{|l|c|c|c|c|c|}
\hline \multicolumn{1}{|c}{ Butir } & (1) & (2) & (3) & (4) & (5) \\
\hline (1) Butir 1 & 1 & & & & \\
\cline { 2 - 6 } (2) Butir 2 & 0.058 & 1 & & & \\
\cline { 2 - 6 } (3) Butir 3 & $0.681^{* *}$ & 0.089 & 1 & & \\
(4) Butir 4 & $0.573^{* *}$ & -0.035 & $0.605^{* *}$ & 1 & \\
\cline { 2 - 6 } (5) Butir 5 & $0.626 * *$ & $0.114^{*}$ & $0.587^{*} *$ & $0.663^{* *}$ & 1 \\
\hline ** Correlation is significant at the 0.01 level. \\
* Correlation is significant at the 0.05 level. \\
\hline
\end{tabular}

Pada Tabel 2, satu-satunya korelasi dengan hungungan berlawanan (walaupun tidak signifikan) terdapat pada Butir 2 dan Butir 4, artinya responden yang lebih suka pergi ke klinik atau rumah sakit selama pembatasan sosial berkala COVID-19 cenderung menyatakan tidak setuju untuk terus menggunakan Telemedis di masa depan. Kemudian, responden yang lebih suka pergi ke klinik atau rumah sakit selama pembatasan sosial berkala COVID-19 cenderung lemah terhadap perubahan pandangan mengenai kebermanfaatan jenis layanan ini.
Tabel 3. Korelasi spearman's rank pada lima butir kuesioner $(n=203)$

\begin{tabular}{|l|c|c|c|c|c|}
\hline Butir & (1) & (2) & (3) & (4) & (5) \\
\hline (1) Butir 1 & 1 & & & & \\
\cline { 2 - 6 } (2) Butir 2 & 0.030 & 1 & & & \\
\cline { 2 - 6 } (3) Butir 3 & $0.687^{* *}$ & 0.048 & 1 & & \\
\cline { 2 - 6 } (4) Butir 4 & $0.559^{* *}$ & -0.072 & $0.592^{* *}$ & 1 & \\
\cline { 2 - 6 } (5) Butir 5 & $0.614^{* *}$ & $0.092^{*}$ & $0.600^{* *}$ & $0.659^{* *}$ & 1 \\
\hline ** Correlation is significant at the 0.01 level. \\
\hline
\end{tabular}

Sama halnya dengan hasil keseluruhan sampel, pada Tabel 3, responden yang lebih suka pergi ke klinik atau rumah sakit selama pembatasan sosial berkala COVID19 cenderung menyatakan tidak setuju untuk terus menggunakan Telemedis di masa depan (walauoun hasil ini tidak signifikan) dan responden yang lebih suka pergi ke klinik atau rumah sakit selama pembatasan sosial berkala COVID-19 cenderung lemah terhadap perubahan pandangan mengenai kebermanfaatan jenis layanan ini.

\subsection{Ordered Logistic Regression (OLR) Models}

Peneliti menggunakan dua butir observasi yang akan dijadikan variable dependen, yang pertama adalah kesediaan responden untuk menggunakan telemedis di masa depan dan yang kedua adalah perubahan pikiran tentang telemedis. Pada kedua variabel tersebut, peneliti menggunakan dua model penelitian. Pertama, peneliti menguji hubungan antara variabel latar belakang yang berupa data demografis responden dengan variabel dependen. Selanjutnya, peneliti menambahkan butir 1 sampai butir 3 pada kuesioner terhadap telemedis.

Setelah menentukan model, peneliti menggunakan metode forward-stepwise sebagai metode pemilihan variabel. Sedangkan untuk pengujuan kecocokan model, beberapa matriks evaluasi dijadikan penilaian. Matriks evaluasi tersebut antara lain adalah Bayesian Information Criterion (BIC), McFadden Pseudo R2, dan Nagelkerke Pseudo R2. Kemudian Uji Likelihood- 
Ratio (LR test) digunakan untuk menguji nested-model. telemedis di masa depan. Namun, pada studi kasus Signifikansi statistik ditetapkan pada nilai-p 0,05. Data (yang dilakukan pada keadaan pembatasan pergerakan dianalisis menggunakan SPSS v.26.

\subsubsection{Prediksi Kesediaan Menggunakan Telemedis di Masa Depan}

Perbedaan nilai AIC dan BIC antara kedua model dan uji LR yang tidak terpaut banyak, dapat menunjukkan bahwa model yang direduksi menunjukkan kecocokan yang lebih baik dengan data daripada model tanpa variabel independen. Meskipun demikian, kedua model mengungkapkan hasil yang sangat mirip mengenai hubungan antara prediktor yang berbeda dan variabel dependen.

Tabel 4. ORL model untuk prediksi kesediaan menggunakan telemedis di masa depan $(n=211)$

\begin{tabular}{|c|c|c|}
\hline Fit indices & Model 1 & Model 2 \\
\hline \multirow{5}{*}{$\begin{array}{l}\text { AIC } \\
\text { BIC } \\
\text { McFadden Pseudo R2 } \\
\text { Nagelkerke Pseudo R2 } \\
\text { Model df }\end{array}$} & 338,243 & 515,744 \\
\hline & 499,133 & 837,523 \\
\hline & 0,08 & 0,45 \\
\hline & 0,228 & 0,784 \\
\hline & 44 & 92 \\
\hline \multicolumn{3}{|c|}{$\begin{array}{c}\text { Note: } A I C=\text { Akaike information criterion } ; B I C=\text { Bayesian } \\
\text { information } \text { criterion }\end{array}$} \\
\hline
\end{tabular}

Pada Tabel 4, AIC dan BIC merupakan metode untuk menilai model fit sanksi untuk jumlah estimasi parameter. Model dengan nilai AIC dan BIC lebih kecil akan menjadi model yang paling dekat dengan model "benar". AIC dan BIC model 1 bernilai lebih kecil daripada Model 2. Namun, nilai Nagelkerke Pseudo R2 pada Model 2 lebih besar dibandingkan Model 1, artinya kemampuan variabel independen dalam menjelaskan variabel dependen pada Model 2 adalah sebesar 0,784 atau 78,4\% dan terdapat $100 \%-78,4 \%=$ $21,6 \%$ faktor lain di luar model yang menjelaskan variabel dependen, sehingga variabel independen pada Model 2 lebih berpengaruh daripada pada Model 1.

Kemudian dapat dilihat pada Tabel 5, serupa dengan analisis korelasi, ketiga butir secara signifikan terkait dengan kesediaan untuk menggunakan telemedis di masa depan. Kemudian tidak terdapat perbedaan signifikan pada sampel keseluruhan dengan sampel khusus responden dewasa.

Tabel 5. ORL model untuk prediksi kesediaan menggunakan telemedis di masa depan $(n=203)$

\begin{tabular}{|c|c|c|}
\hline Fit indices & Model 1 & Model 2 \\
\hline \multirow{5}{*}{$\begin{array}{l}\text { AIC } \\
\text { BIC } \\
\text { McFadden Pseudo R2 } \\
\text { Nagelkerke Pseudo R2 } \\
\text { Model df }\end{array}$} & 316,473 & 502,032 \\
\hline & 462,254 & 806,847 \\
\hline & 0,074 & 0,435 \\
\hline & 0,212 & 0,771 \\
\hline & 40 & 88 \\
\hline \multicolumn{3}{|c|}{$\begin{array}{c}\text { Note: } \text { AIC }=\text { Akaike information criterion } ; \text { BIC }=\text { Bayesian } \\
\text { information criterion }\end{array}$} \\
\hline
\end{tabular}

Singkatnya, sementara hanya $32,7 \%$ dari responden dewasa tidak setuju atau tidak sepenuhnya setuju Berbagai penelitian dan survei yang dilakukan selama bahwa mereka akan terus menggunakan layanan masa ini menemukan bahwa kepuasan yang tinggi 
terhadap telemedis yang diberikan [21]. Temuan pada penelitian ini konsisten dengan laporan ini [22], yang menunjukkan kepuasan tinggi dengan layanan [2] telemedis.

Seseorang cenderung memiliki kebutuhan yang kuat untuk mempertahankan konsistensi kognitif [23], cenderung bertindak dengan cara yang konsisten [3] dengan tindakan atau perilaku sebelumnya [24], dan telah ditemukan bahwa perilaku masa lalu dapat menjadi prediktor perilaku masa depan [25].

\section{Kesimpulan}

Di Indonesia, pandemi COVID-19 telah mempercepat penggunaan perkembangan penggunaan Telemedis. Studi ini meneliti sikap orang dewasa terhadap penggunaan telemedis selama pembatasan berkala dan adaptasi kebiasaaan baru COVID-19. Berbeda dengan penelitian sebelumnya yang dilakukan pada lingkungan yang sepenuhnya dilaksanakan penguncian ketat (lockdown), masa pembatasan berkala dan adaptasi kebiasaan baru di Indonesia hanya menerapkan kebijakan pembatasan mobilisasi dan banyak dari berbagai sektor industri dan pengusaha tetap melaksanakan kegiatan produksi perkandotan, serta bisnis mereka secara terbatas. Hasil penelitian menunjukkan bahwa sebagian besar responden lebih suka menggunakan telemedis dan puas dengan penggunaannya selama periode ini. Sistem kesehatan perlu menyediakan perawatan medis virtual bila memungkinkan untuk menjaga pasien di rumah sambil tetap menawarkan akses ke perawatan medis yang diperlukan.

Sebelum pandemi COVID-19, telemedis di Indonesia kurang diminati atau menjadi alternatif sekunder untuk mengunjungi klinik. Kemudian setelah hadirnya COVID-19 dan munculnya beragam kebijakan pembatasan sosial dan mobilisasi dengan cepat mengubah gambaran tentang penggunaan telemedis, karena sebagian besar responden terpaksa menggunakan telemedis sebagai alternatif yang hampir utama. Peneliti mengusulkan bahwa perubahan perilaku yang didorong ini memicu perubahan sikap responden terhadap telemedis, sehingga meningkatkan kesediaan mereka untuk menggunakannya di masa yang akan datang. Tantangannya, tentu saja, adalah untuk melanjutkan tren dan menetapkan penggunaan telemedis sebagai alternatif utama yang setara dengan pengobatan tatap muka dalam pengaturan klinis

Kemudian, untuk penelitian selajutnya diharapkan dapat lebih merinci faktor-faktor dan sikap yang [14] mempengaruhi setiap butir penelitian dengan beragam metode. Adapun saran untuk penelitian selanjutnya lainnya adalah untuk mengetahui alasan masyarakat bertahan ataupun tidak mau bertahan menggunakan telemedis selepas Covid-19.

\section{Daftar Rujukan}

[1] Tim BPS Covid-19 Statistical Task Force, Hasil Survei
Perilaku Masyarakat Di Masa Pandemi Covid-19 (7-14 September 2020), vol. 19, no. September. 2020.

S. A. Soenarso and Handoyo, "Survei Markplus: Masyarakat enggan mengunjungi rumah sakit sejak pandemi Covid-19," kontan.co.id, 2020. https://nasional.kontan.co.id/news/surveimarkplus-masyarakat-enggan-mengunjungi-rumah-sakitsejak-covid-19 (accessed Sep. 17, 2021).

E. Laurenza, M. Quintano, F. Schiavone, and D. Vrontis, "The effect of digital technologies adoption in healthcare industry: a case based analysis," Bus. Process Manag. J., vol. 24, no. 5, pp. 1124-1144, Jan. 2018, doi: 10.1108/BPMJ-04-2017-0084.

[4] M. Esposito, A. Minutolo, R. Megna, M. Forastiere, M. Magliulo, and G. De Pietro, "A smart mobile, selfconfiguring, context-aware architecture for personal health monitoring," Eng. Appl. Artif. Intell., vol. 67, pp. 136-156, 2018, doi: https://doi.org/10.1016/j.engappai.2017.09.019.

Y. Zhao, Q. Ni, and R. Zhou, "What factors influence the mobile health service adoption? A meta-analysis and the moderating role of age," Int. J. Inf. Manage., vol. 43, pp. 342350, 2018, doi: https://doi.org/10.1016/j.ijinfomgt.2017.08.006.

D. H. Jaffe, L. Lee, S. Huynh, and T. P. Haskell, "Health Inequalities in the Use of Telehealth in the United States in the Lens of COVID-19," Popul. Health Manag., vol. 23, no. 5, pp. 368-377, Aug. 2020, doi: 10.1089/pop.2020.0186.

[7] S. Sadegh, P. Saadat, M. M. Sepehri, and V. Assadi, "A framework for m-health service development and success evaluation," Int. J. Med. Inform., vol. 112, pp. 123-130, Apr. 2018, doi: 10.1016/j.ijmedinf.2018.01.003.

A. Beratarrechea, A. G. Lee, J. M. Willner, E. Jahangir, A. Ciapponi, and A. Rubinstein, "The impact of mobile health interventions on chronic disease outcomes in developing countries: a systematic review," Telemed. J. E. Health., vol. 20, no. 1, pp. 75-82, Jan. 2014, doi: 10.1089/tmj.2012.0328.

[9] L. Wallis, P. Blessing, M. Dalwai, and S. Do Shin, "Integrating mHealth at point of care in low- and middleincome settings: the system perspective.," Glob. Health Action, vol. 10, no. sup3, p. 1327686, Jun. 2017, doi: 10.1080/16549716.2017.1327686.

[10] A. Doshi, Y. Platt, J. R. Dressen, B. K. Mathews, and J. C. Siy, "Keep calm and $\log$ on: Telemedicine for COVID-19 pandemic response," J. Hosp. Med., vol. 15, no. 5, pp. 302304, 2020, doi: 10.12788/jhm.3419.

11] J. Vidal-Alaball et al., "Telemedicine in the face of the COVID-19 pandemic," Aten. primaria, vol. 52, no. 6, pp. 418-422, 2020, doi: 10.1016/j.aprim.2020.04.003.

[12] B. A. Oktavira, "Aturan tentang Konsultasi Dokter Jarak Jauh (Telemedicine)," Klinik Hukumonline, Oct. 25, 2019. https://www.hukumonline.com/klinik/detail/ulasan/lt5db2b3d 5e618b/aturan-tentang-konsultasi-dokter-jarak-jauhitelemedicine-i/ (accessed Sep. 17, 2021).

[13] E. Whaibeh, H. Mahmoud, and H. Naal, "Telemental Health in the Context of a Pandemic: the COVID-19 Experience," Curr. Treat. options psychiatry, pp. 1-5, Apr. 2020, doi: 10.1007/s40501-020-00210-2.

14] R. A. Machado, N. L. de Souza, R. M. Oliveira, H. Martelli Júnior, and P. R. F. Bonan, "Social media and telemedicine for oral diagnosis and counselling in the COVID-19 era.," Oral oncology, vol. 105 . p. 104685, Jun. 2020, doi: 10.1016/j.oraloncology.2020.104685.

[15] S. Reicher, T. Sela, and O. Toren, "Using Telemedicine During the COVID-19 Pandemic: Attitudes of Adult Health Care Consumers in Israel," Front. Public Heal., vol. 9, no. May, pp. 1-11, 2021, doi: 10.3389/fpubh.2021.653553. 
[16] A. Miyawaki, T. Tabuchi, M. K. Ong, and Y. Tsugawa, "Age [21] and Social Disparities in the Use of Telemedicine During the COVID-19 Pandemic in Japan: Cross-sectional Study.," J. Med. Internet Res., vol. 23, no. 7, p. e27982, Jul. 2021, doi: $10.2196 / 27982$.

[17] S. Orrange, A. Patel, W. J. Mack, and J. Cassetta, "Patient [22] Satisfaction and Trust in Telemedicine During the COVID-19 Pandemic: Retrospective Observational Study," JMIR Hum Factors 2021;8(2)e28589 https//humanfactors.jmir.org/2021/2/e28589, vol. 8, no. 2, p. e28589, Apr. 2021, doi: 10.2196/28589.

[18] M. Deidda, M. Meleddu, and M. Pulina, "Potential users' preferences towards cardiac telemedicine: A discrete choice experiment investigation in Sardinia," Heal. Policy Technol., vol. 7, no. 2, pp. 125-130, Jun. 2018, doi: 10.1016/J.HLPT.2018.04.002.

[19] R. A. Neher, R. Dyrdak, V. Druelle, E. B. Hodcroft, and J. Albert, "Potential impact of seasonal forcing on a SARS-CoV2 pandemic.," Swiss Med. Wkly., vol. 150, p. w20224, Mar. 2020, doi: 10.4414/smw.2020.20224.

[20] E. K. Stokes et al., "Coronavirus Disease 2019 Case Surveillance - United States, January 22-May 30, 2020.," MMWR. Morb. Mortal. Wkly. Rep., vol. 69, no. 24, pp. 759765, Jun. 2020, doi: 10.15585/mmwr.mm6924e2.
D.-Q. Pham, S. A. Golub, C. C. Breuner, and Y. N. Evans, "The Impact of Telehealth on Clinical Education in Adolescent Medicine During the COVID-19 Pandemic: Positive Preliminary Findings," Front. Pediatr., vol. 9, p. 210 , 2021, doi: 10.3389/fped.2021.642279.

M. Hilbert, "Digital gender divide or technologically empowered women in developing countries? A typical case of lies, damned lies, and statistics," Womens. Stud. Int. Forum, vol. 34, no. 6, pp. 479-489, 2011, doi: https://doi.org/10.1016/j.wsif.2011.07.001

[23] B. Gawronski and F. Strack, Eds., Cognitive Consistency: A Fundamental Principle in Social Cognition - Google Books. New York: The Guiford Press, 2012.

[24] D. Albarracín and R. S. Wyer Jr., "The cognitive impact of past behavior: Influences on beliefs, attitudes, and future behavioral decisions." Journal of Personality and Social Psychology, vol. 79, no. 1. American Psychological Association, US, pp. 5-22, 2000, doi: 10.1037/00223514.79.1.5

[25] J. A. Ouellette and W. Wood, "Habit and intention in everyday life: The multiple processes by which past behavior predicts future behavior.", Psychological Bulletin, vol. 124, no. 1. American Psychological Association, US, pp. 54-74, 1998, doi: 10.1037/0033-2909.124.1.54. 